\title{
Rapid and Sensitive Detection of Lettuce Necrotic Yellows Virus and Cucumber Mosaic Virus Infecting Lettuce (Lactuca sativa L.) by Reverse Transcription Loop-Mediated Isothermal Amplification
}

\author{
Yubao Zhang $\mathbb{D}^{1}{ }^{1}$, Zhongkui Xie ${ }^{1 *}$, John D Fletcher ${ }^{2}$, Yajun Wang ${ }^{1}$, Ruoyu Wang ${ }^{1}$, Zhihong Guo ${ }^{1}$, and Yuhui He \\ ${ }^{1}$ Northwest Institute of Eco-Environment and Resources, Chinese Academy of Sciences, Lanzhou 730000, China \\ ${ }^{2}$ The New Zealand Institute for Plant and Food Research, PB 4704 Christchurch, New Zealand
}

(Received on December 16, 2019; Accepted on January 10, 2020)

Cucumber mosaic virus (CMV) is damaging to the growth and quality of lettuce crops in Lanzhou, China. Recently, however, for the first time an isolate of lettuce necrotic yellows virus (LNYV) has been detected in lettuce crops in China, and there is concern that this virus may also pose a threat to lettuce production in China. Consequently, there is a need to develop a rapid and efficient detection method to accurately identify LNYV and CMV infections and help limit their spread. Reverse transcription loop-mediated isothermal amplification (RT-LAMP) assays were developed to detect the nucleoprotein $(N)$ and coat protein $(C P)$ genes of LNYV and CMV, respectively. RT-LAMP amplification products were visually assessed in reaction tubes separately using green fluorescence and gel electrophoresis. The assays successfully detected both viruses in infected plants without cross reactivity recorded from either CMV or LNYV or four other related plant viruses. Optimum LAMP reactions were conducted in betaine-free media with $6 \mathrm{mM} \mathrm{Mg}^{2+}$ at $65^{\circ} \mathrm{C}$ for LNYV and $60^{\circ} \mathrm{C}$ for $60 \mathrm{~min}$ for $\mathrm{CMV}$, respectively. The detection limit was $3.5 \mathrm{pg} / \mathrm{ml}$ and $20 \mathrm{fg} / \mathrm{ml}$ using RT-LAMP for LNYV and CMV plasmids, respectively. Detection sensitivity

\footnotetext{
*Corresponding author.

Phone) +86-931-4967204, FAX) +86-931-8273894

E-mail)wxhcas@1zb.ac.cn

ORCID

Yubao Zhang

https://orcid.org/0000-0001-8438-0810

(c) This is an Open Access article distributed under the terms of the Creative Commons Attribution Non-Commercial License (http:// creativecommons.org/licenses/by-nc/4.0) which permits unrestricted noncommercial use, distribution, and reproduction in any medium, provided the original work is properly cited.
}

Articles can be freely viewed online at www.ppjonline.org. for both RT-LAMP assays was greater by a factor of 100 compared to the conventional reverse transcription polymerase chain reaction assays. This rapid, specific, and sensitive technique should be more widely applied due to its low cost and minimal equipment requirements.

Keywords : cucumber mosaic virus, lettuce, lettuce necrotic yellows virus, RT-LAMP amplification, RT-PCR

Handling Editor : Ho-Jong Ju

Lettuce (Lactuca sativa L.) is the most economically important vegetable crop belonging to the family Asteraceae (Krause-Sakate et al., 2001) and is typically eaten cold, raw, in salads, sandwiches, hamburgers, tacos as well as in many other dishes around the world (Fletcher et al., 2005; Wikipedia, 2019). In China, the economic importance of lettuce has also greatly increased during the past decade because of the rapid increase in demand for this crop, which is now exceeding half the world's production. However, lettuce is susceptible to a number of viral pathogens, including Cucumber mosaic virus (genus: Cucumovirus; family: Bromoviridae). Cucumber mosaic virus (CMV) is one of the most widespread plant viruses with an extensive host range, infecting approximately 1,000 species in over 100 plant families that include cereals, fruits, vegetables and ornamentals, and can cause significant economic losses for numerous vegetable and horticultural crops (Roossinck, 1999). In lettuce plants symptoms caused by CMV include plant stunting, leaf chlorosis, and mosaic as well as poor head formation (Bruckart and Lorbeer, 1975; El-Borollosy and Waziri, 2013). The virus is readily transmitted in a non-persistent manner by more than 75 species of aphids 
(Palukaitis et al., 1992). It may also be transmitted mechanically and can be seed-borne in a number of hosts.

In 2018, a preliminary field survey was conducted in a major lettuce cultivation area in Lanzhou City, Gansu Province, China. This survey detected lettuce necrotic yellows virus (LNYV) for the first time in fields around Shichuan Town (Gaolan County, Lanzhou City, Gansu Province, China; $\left.36^{\circ} 10^{\prime \prime} \mathrm{N}, 103^{\circ} 59^{\prime \prime} \mathrm{E}\right)$. The main symptoms observed were plant stunting, leaf chlorosis, leaf roughness and occasional necrosis within leaf tissue. Mosaic symptoms were also present and attributed to a mixed LNYV infection of both CMV and lettuce mosaic virus (LMV) (Fig. 1). LNYV is a member of the genus Cytorhabdovirus, family Rhabdoviridae (Tordo et al., 2005). Infection by members of the genus Cytorhabdoviridae is characterized by the accumulation of enveloped virions in the cytoplasm of host cells (Jackson et al., 2005). LNYV causes a serious disease of lettuce crops grown in both Australia and New Zealand, with the first reports published in 1963 and 1973, respectively (Fry et al., 1973; Stubbs and Grogan, 1963), and it continues to cause crop losses of up to $70 \%$ in some cultivated areas (Fletcher et al., 2017; unpublished report). There also have been isolated reports of similar lettuce virus infections in Spain (Rubio-Huertos and Garcia-Hidalgo, 1982), Italy (Ragozzino et al., 1989), and Great Britain (Blancard et al., 2006). LNYV is transmitted in a persistent, propagative manner by the blackcurrant-sowthistle aphid (Hyperomyzus lactucae L.) (Higgins et al., 2016). Ragozzino et al. (1989) also determined that the currantlettuce aphid (Nasonovia ribisnigri) was the primary vector of LNYV disease outbreaks in Italy.

Viral disease management is dependent upon an accurate detection procedure which is convenient, reproducible and scalable for a wide range of samples (Viswanathan et al., 2013). Currently available methods commonly used for detecting viruses that affect lettuce include enzyme-linked immunosorbent assay (ELISA), reverse transcription (RT)polymerase chain reaction (PCR) for LNYV and CMV (Callaghan and Dietzgen, 2005; Deyong et al., 2005; Dietzgen and Francki, 1988; Koenig, 1981) and immunocapture (IC)-RT-PCR for CMV (El-Borollosy and Waziri, 2013). These methods are valuable for identifying latent infections at most stages of infection. However, false negative results and low sensitivity are common problems for the ELISA method. Moreover, PCR-based methods are expensive in terms of time and equipment and hence impractical for large-scale use. The IC-RT-PCR technique omits the need to isolate RNA while providing a more rapid and less costly approach to prepare templates for amplification (Gambley et al., 2009); however, we have found IC-RTPCR sensitivity insufficient in detecting low CMV concentrations (Zhang et al., 2017).

On the other hand, the loop-mediated isothermal amplification of nucleic acids (LAMP) assay, is not only sensitive and relatively inexpensive to use but can also be routinely conducted at a constant temperature between $58-70^{\circ} \mathrm{C}$ for approximately $1 \mathrm{~h}$ in a water bath or on a heating block. The technique can also be used for amplifying RNA by adding reverse transcriptase to the LAMP reaction mixture (often referred to as RT-LAMP) (Bhat et al., 2013). Both LAMP and RT-LAMP use four to six primers along with DNA polymerization with strand-displacing activity to generate amplification products. These products can be visually detected using agarose gel electrophoresis or through color changes visualized by adding SYBR Green I, ethidium bromide or calcein to the reaction mixture (Notomi et al., 2000; Parida et al., 2008). Both methods have been successfully used in the detection of many DNA- (Bhat et al., 2013; Ravindran et al., 2012) and RNA-based (He et al., 2016; Liu et al., 2010; Zhao et al., 2010) plant pathogens. In this study, we developed and optimized a simple, rapid, reliable and visual RT-LAMP method for the accurate de-

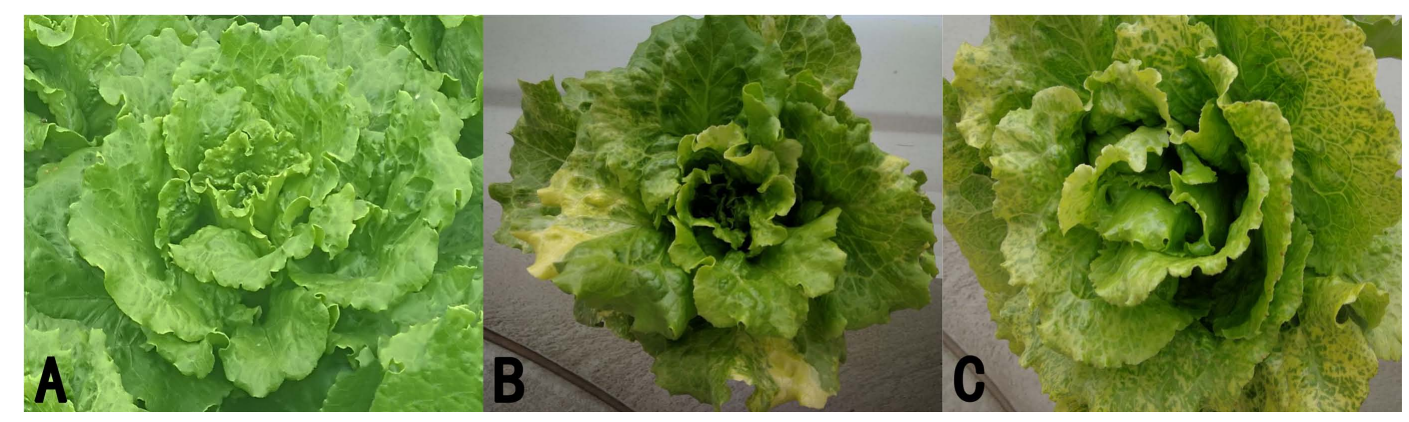

Fig. 1. Healthy lettuce plant (A) and lettuce plant (B) infected with lettuce necrotic yellows virus (LNYV) exhibiting symptoms of plant stunting, leaf chlorosis, leaf roughness and intermittent necrosis within the leaf tissue. (C) Mosaic symptoms also present were attributed to the mixed infection of LNYV with both cucumber mosaic virus (CMV) and lettuce mosaic virus (LMV). 
tection of LNYV and CMV infections in lettuce plants.

\section{Materials and Methods}

Plant sample collection and reference virus isolates. Within the cultivation areas of Shichuan and Donggang towns, Lanzhou City, China, we collected naturally infected lettuce leaf samples that displayed typical viral symptoms (i.e., plant stunting, leaf chlorosis, leaf roughness and intermittent necrosis in leaf tissues). From field experience gained in New Zealand and from employing known (tested) positives of viruses from New Zealand used here as references (Fletcher et al., 2017; unpublished), lettuce leaves were tested using RT-PCR to confirm their respective virus infection status. Lettuce leaf samples from individual plants that tested positive for LNYV or CMV served as a reference source of each virus and were stored at $-70^{\circ} \mathrm{C}$ prior to analysis. Other virus reference sources for our experiments, each isolated from lily (Lilium oriental cv. Sorbonne), included lily symptomless virus (LSV), a CMV lily isolate, lily mottle virus (LMoV), and arabis mosaic virus (ArMV) (Zhang et al., 2017; Zhang, unpublished data).

RT-LAMP primer design. The conserved regions of nucleoprotein $(\mathrm{N})$ and coat protein $(\mathrm{CP})$ genes were used as the basis for the design of the RT-LAMP primers for LNYV and CMV detection. This was done by establishing sequence alignments (multiple sequence alignment) of $\mathrm{N}$ and $\mathrm{CP}$ gene sequences of LNYV and CMV isolated from lettuce available in GenBank (accession Nos. AJ746190.1 and AJ810253), respectively (Callaghan and Dietzgen, 2005; Deyong et al., 2005). Primer design was conducted using PrimerExplorer version 5 software (Eiken Chemical Co., Ltd., Japan) with the default settings. Two LAMP external primers (F3 and B3) and two internal primers (FIP [F1c + F2] and BIP [B1c + F2]) as well as a pair of loop primers (F-loop and B-loop) and a single loop primer (Bloop) for LNYV and CMV detection were respectively designed and were capable of detecting a total of eight sequences of the $\mathrm{N}$ gene of LNYV and seven sequences of the CP gene of CMV (sequences shown in Table 1).

RNA extraction. Total RNA was extracted from each lettuce leaf sample of about $100 \mathrm{mg}$ (fresh weight) using the RNAprep Pure Kit (For Plant) (Tiangen Biotech Co. Ltd., Beijing, China) according to the manufacturer's instructions. The final elution step was conducted using $50 \mu \mathrm{l}$ of RNAse-free $\mathrm{H}_{2} \mathrm{O}$. The concentration of the RNA sample was measured with a NanoDrop ND-1000 Spectrophotometer (NanoDrop Technologies LLC, Wilmington, DE,
USA).

Cloning, sequencing, and sequence analysis. The firststrand viral cDNA was synthesized with the PrimeScript RT Reagent Kit with gDNA Eraser (Takara Biotechnology Co., Ltd., Dalian, China) using random hexamers. PCR was carried out in $12.5 \mu \mathrm{l}$ reaction volumes containing 1.0 $\mu \mathrm{l}$ of the cDNA products, $1.25 \mu \mathrm{l}$ of a $10 \times$ PCR buffer $(100$ $\mathrm{mmol} / \mathrm{l} \mathrm{Tris-HCl}$ [pH 8.3], $500 \mathrm{mmol} / \mathrm{l} \mathrm{KCl}, 15 \mathrm{mmol} /$ $1 \mathrm{MgCl}_{2}$ ), $0.4 \mathrm{mmol}$ of a dNTP mixture, $0.3 \mathrm{U}$ of Taq polymerase (TaKaRa Ex Taq, Takara) and $0.1 \mu \mathrm{M}$ of each LNYV-F and LNYV-R (or CMV-F and CMV-R) primers (Table 1). Both PCR amplification consisted of 35 cycles at $94^{\circ} \mathrm{C}$ for $30 \mathrm{~s}, 52^{\circ} \mathrm{C}$ for $45 \mathrm{~s}$ and $72^{\circ} \mathrm{C}$ for $1 \mathrm{~min}$.

Amplified PCR products were purified using the Agarose Gel DNA Fragment Recovery Kit (Takara) and purified fragments were cloned into the pMD18-T vector (Takara). The ligates were transformed into competent cells of the Escherichia coli strain DH5a. Plasmid DNA preparations were obtained using the TaKaRa MiniBEST Agarose Gel DNA Extraction Kit (Takara). The cloned plasmid was denoted either pMD18-LNYV or pMD18-CMV, and the presence of the inserted PCR products was confirmed by means of agarose gel electrophoresis and a sequence assay. Sequencing was performed at the Sangon Biotech (Shanghai) Co., Ltd. (Shanghai, China). Sequences were analyzed using the Basic Local Alignment Search Tool (BLAST) for virus identification within species.

LAMP and its optimization. The LAMP reaction was conducted in $12.5 \mu \mathrm{l}$ reaction volumes that contained 0.5 $\mu \mathrm{l}$ of the cDNA products (50 ng), $1.25 \mu \mathrm{l}$ of a $10 \times$ ThermpoPol buffer (New England BioLabs, Ipswich, MA, USA), a final concentration of $6 \mathrm{mM} \mathrm{MgSO}_{4}, 0.8 \mathrm{M}$ betaine (Sigma-Aldrich, St. Louis, MO, USA), $1.4 \mathrm{mM}$ dNTPs, $2 \mu \mathrm{M}$ each of the external primers (F3 and B3), $1.6 \mu \mathrm{M}$ each of the internal primers (FIP and BIP), $0.4 \mu \mathrm{M}$ each of the loop primers and $4 \mathrm{U}$ of Bst DNA polymerase (New England BioLabs). Betaine has typically been used as an additive for isothermal nucleic acid amplification reactions because it lowers the melting temperature (Tm) of DNA; however, there is some doubt as to its efficacy for all LAMP reaction systems (Ma et al., 2017). Following these steps, we determined the optimum incubation temperature, duration and concentration of $\mathrm{MgSO}_{4}$ and betaine in each primer set of LNYV and CMV used for the RT-LAMP assays.

To determine the optimum temperature, the reaction was conducted for $100 \mathrm{~min}$ at seven different temperatures: 56 , $58,60,62,65,68$, and $70^{\circ} \mathrm{C}$ followed by $80^{\circ} \mathrm{C}$ for $10 \mathrm{~min}$ in a thermal cycler (Bio-Rad, Hercules, CA, USA). To de- 
Table 1. Primer sequences used for RT-LAMP and RT-PCR for the detection of LNYV and CMV

\begin{tabular}{llll}
\hline $\begin{array}{l}\text { Primer } \\
\text { names }\end{array}$ & \multicolumn{1}{c}{ Type } & \multicolumn{1}{c}{ Position $^{\mathrm{a}}$} & \multicolumn{1}{c}{ Sequence (5'-3') } \\
\hline LNYV-F3 & Forward outer primer for RT-LAMP & $420-439$ & ACCTAAGCCAGCAATGACAT \\
LNYV -B3 & Backward outer primer for RT-LAMP & $644-661$ & TGCCCAATCCAGCCTCTT \\
LNYV-FIP & Forward inner primer (F1c-F2) for & F1 $_{\mathrm{C}}: 503-524$, & CTGTTAGATACTCCCGCCTGCGA- \\
& RT-LAMP & F2: $447-466$ & CACCTCCTAACACCTCCTT \\
LNYV-BIP & Backward inner primer (B1c-B2) for & B1 $1_{\mathrm{C}}: 503-524$, & CTCTGGACGCAACCCGGAAGATTGCTTCG- \\
& RT-LAMP & B2: $604-623$ & TACCTAGCCCT \\
LNYV -LF & F-loop primer for RT-LAMP & $618-636$ & CGAGCCTAGTACCTTGATCTGAAG \\
LNYV -LB & B-loop primer for RT-LAMP & $815-832$ & AATTTGTTGACTGAGACTGATGAGG \\
LNYV-F & For RT-PCR & $194-210$ & CTAGGGTCAGGAACACAGCG \\
LNYV -B & For RT- PCR & $781-807$ & ATACCATGCCGCGAATCTGT \\
CMV-F3 & Forward outer primer for RT-LAMP & $439-456$ & TGGCGATGGTAATTCACCG \\
CMV-B3 & Backward outer primer for RT-LAMP & $620-638$ & CGGGAGCATCCGTGAGAT \\
CMV-FIP & Forward inner primer (F1c-F2) for & F1 $: 515-533$, & ACGCACCTCGGACAGGTCATTATGCTGC- \\
& RT-LAMP & F2: $458-477$ & GTCCGGAGTT \\
CMV-BIP & Backward inner primer (B1c-B2) for & B1 $: 539-560$, & CATGCGTAAGTACGCCGTCCTCGACGTCGA- \\
& RT-LAMP & B2: $600-619$ & CATGAAGTACA \\
CMV-LB & B-loop primer for RT-LAMP & $568-592$ & AAAGACGATAAACTAGAGAAGGACG \\
CMV-F & For RT-PCR & $171-193$ & TCGGTCCGCTTCTGGT \\
CMV-B & For RT-PCR & $418-435$ & TCGGGAGCATCCGTGAG \\
\hline RT-LAMP, & & &
\end{tabular}

RT-LAMP, reverse transcription loop-mediated isothermal amplification; RT-PCR, reverse transcription polymerase chain reaction; LNYV, lettuce necrotic yellows virus; CMV, cucumber mosaic virus.

${ }^{a}$ Gene position based on the nucleotide sequence of LNYV nucleoprotein (N) and CMV coat protein (CP) (GenBank accession Nos. AJ746190.1 and AJ810253), respectively.

termine the optimum duration (time), the reaction was conducted at $58^{\circ} \mathrm{C}$ and $60^{\circ} \mathrm{C}$ under five different time periods $\left(20,40,60,80\right.$, and $100 \mathrm{~min}$ ) followed by $80^{\circ} \mathrm{C}$ for $10 \mathrm{~min}$ for LNYV and CMV detection, respectively.

To determine the optimum $\mathrm{MgSO}_{4}$ concentration, the reaction was conducted at $58^{\circ} \mathrm{C}$ and $60^{\circ} \mathrm{C}$ for $60 \mathrm{~min}$ at eight different $\mathrm{MgSO}_{4}$ concentrations: 0, 2, 4, 6, 8, 10, 12, and $14 \mathrm{mM}$ for LNYV and CMV detection, respectively. To determine the optimum betaine concentration, the reaction was conducted at $58^{\circ} \mathrm{C}$ and $60^{\circ} \mathrm{C}$ for $60 \mathrm{~min}$ at seven different betaine concentrations: $0,0.4,0.8,1.2,1.6,2.0$, and $2.4 \mathrm{M}$ for LNYV and CMV detection, respectively.

LAMP amplification products $(5 \mu \mathrm{l})$ were analyzed and evaluated by direct visual inspection of the reaction tube after the addition of SYBR Green I (Invitrogen, Carlsbad, CA, USA) (1:1,000 TE; v/v). In addition, LAMP amplification products $(5 \mu \mathrm{l})$ were routinely detected using agarose gel electrophoresis ( $2.0 \%$ agarose; TAE).

RT-PCR. The primer pair designated LNYV-F and LNYV-R (or CMV-F and CMV-R) was based on the conserved region of the LNYV N gene (or the CMV CP gene) and used for RT-PCR analysis. Primer pair sequences are provided in Table 1. As described above, total RNA was extracted from lettuce plants that tested positive for LNYV or CMV using the RNAprep Pure Kit (For Plant). Subsequently, RT was performed to synthesize the first strand of cDNA according to the procedures described above, while PCR was conducted in $12.5 \mu \mathrm{l}$ reaction volumes according to the procedures described above. A $5.0 \mu \mathrm{l}$ volume of the PCR product was verified by electrophoresis on a $2.0 \%$ agarose gel and were of the expected sizes (i.e., 614 and $587 \mathrm{bp}$ for LNYV and CMV, respectively).

Analysis of RT-LAMP specificity. Total RNA extracts from lily and lettuce leaves infected with LSV, the CMV lily isolate, LMoV, ArMV, LNYV, and the CMV lettuce isolate were used to evaluate the cross reactivity of the RTLAMP assay. A $0.5 \mu \mathrm{l}$ volume of total RNA (100 ng/ $\mu \mathrm{l})$ was added to the reaction mixture. Water and healthy lettuce leaves were used as the blank and negative controls, respectively.

Comparison between RT-LAMP and RT-PCR sensitivities. To compare the sensitivity of RT-LAMP to RTPCR, the pMD18-LNYV or pMD18-CMV plasmids were serially diluted 10 -fold from $3.5 \times 10^{5}$ to $3.5 \times 10^{-4} \mathrm{ng} / \mathrm{ml}$ or from $2.0 \times 10^{5}$ to $2.0 \times 10^{-6} \mathrm{ng} / \mathrm{ml}$, respectively. A $0.5 \mu \mathrm{l}$ 
volume of each dilution was added to the LAMP or PCR mixture.

Evaluation of RT-LAMP using field-collected samples. To validate the RT-LAMP assays, 16 leaf samples were collected from lettuces at different growth stages including seedling, rosette or lotus, and heading. Specimens exhibited virus-like symptoms and were collected from seven fields located in two towns, Shichuan and Donggang around Lanzhou City, Gansu Province, China, and tested for LNYV and CMV using RT-LAMP assays. RT-LAMP amplification products $(5 \mu \mathrm{l})$ were detected using agarose gel electrophoresis (2.0\% agarose; TAE) and by direct visual examination with the addition SYBR Green I. Also, for comparison, each leaf sample was tested using RT-PCR according to the above method.

\section{Results}

Confirmation of virus identities. Sequences from samples of each virus analyzed using the nucleotide-nucleotide BLAST (Blastn) tool showed that cloned LNYV and
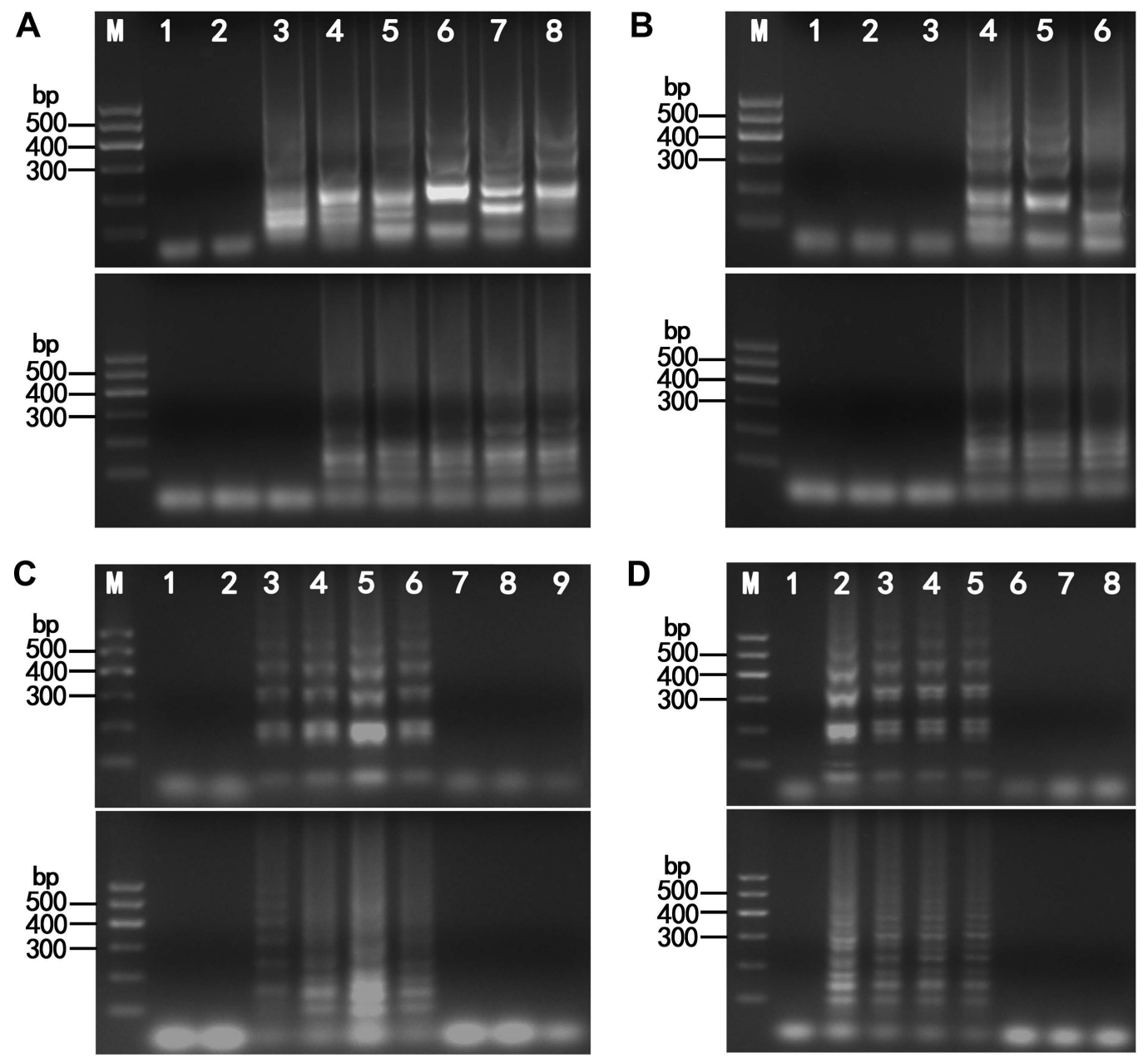

Fig. 2. Agarose gel electrophoresis showing the effect of amplification temperatures (A), reaction durations (B), different concentrations of $\mathrm{MgSO}_{4}(\mathrm{C})$ and of betaine (D) on the detection of lettuce necrotic yellows virus (LNYV) and cucumber mosaic virus (CMV) using reverse transcription loop-mediated isothermal amplification (RT-LAMP). (A) Temperature. Lanes loaded with LNYV (upper) and CMV (lower) products of RT-LAMP assays conducted at different temperatures. Lane M: DL600 marker; lane 1: negative control; lanes 2-8: $56,58,60,62,65,68$, and $70^{\circ} \mathrm{C}$. (B) Time duration. Lanes loaded with LNYV (upper) and CMV (lower) products of RT-LAMP assays conducted over different durations. Lane M: DL600 marker; lane 1: negative control; lanes 2-6: 20, 40, 60, 80, and 100 min. (C) MgSO . Lanes loaded with LNYV (upper) and CMV (lower) products of RT-LAMP assays conducted using different concentrations of $\mathrm{MgSO}_{4}$. Lane M: DL600 marker; lane 1: water control; lanes 2-9: 0, 2, 4, 6, 8, 10, 12, and 14 mM. (D) Betaine. Lanes loaded with LNYV (upper) and CMV (lower) products of RT-LAMP assays conducted using different concentrations of betaine. Lane M: DL600 marker; lane 1: water control; lanes 2-8: 0, 0.4, 0.8, 1.2, 1.6, 2.0, and 2.4 M. 
CMV fragments shared $98.7 \%$ and $98 \%$ homology, respectively, to a known LNYV lettuce isolate (GenBank No. KP109949.1) and to a known CMV lettuce isolate (GenBank No. AJ810253). The sequence of cloned LNYV fragment was submitted to GenBank at the National Center for Biotechnology Information (NCBI) under accession number (MK850384).

Optimization of LAMP reactions. The optimum temperatures for detecting LNYV and CMV using RT-LAMP were confirmed through 100 min RT-LAMP reactions at seven different temperatures, between $56^{\circ} \mathrm{C}$ and $70^{\circ} \mathrm{C}$. After a $100 \mathrm{~min}$ incubation period, reaction products were analyzed by electrophoresis. No amplification was seen at $56^{\circ} \mathrm{C}$; whereas amplification was evident at 58, 60, 62, 65, 68 , and $70^{\circ} \mathrm{C}$ however the strongest reaction was observed at $65^{\circ} \mathrm{C}$ for LNYV detection (Fig. 2A, upper). Similarly for $\mathrm{CMV}$, no amplification was seen at $56^{\circ} \mathrm{C}$ and $58^{\circ} \mathrm{C}$ but was evident at $60,62,65,68$, and $70^{\circ} \mathrm{C}$ but with no obvious difference (Fig. 2A, lower). Therefore, the optimum temperature was selected as $65^{\circ} \mathrm{C}$ for LNYV and $60^{\circ} \mathrm{C}$ for CMV. To determine the minimum reaction time of LNYV and CMV detection, LAMP was conducted at $65^{\circ} \mathrm{C}$ and $60^{\circ} \mathrm{C}$ for $20,40,60,80$, and $100 \mathrm{~min}$. Typical ladder-like patterns were clearly observed at 60,80 , and $100 \mathrm{~min}$; however, no amplification was observed at 20 and $40 \mathrm{~min}$ for either virus (Fig. 2B). Consequently, the minimum reaction time was determined as $60 \mathrm{~min}$ for both viruses.

The optimum $\mathrm{MgSO}_{4}$ concentration in our experiment was $6 \mathrm{mM}$ for both viruses (Fig. 2C). The optimum betaine concentration for LAMP detection of LNYV and CMV was determined by testing a range of betaine concentrations (i.e., from 0 to $2.4 \mathrm{M}$ ). Typical ladder-like patterns were clearly observed by agarose gel electrophoresis without betaine. Ladder-like patterns were observed at $0.4,0.8$, and $1.2 \mathrm{M}$ betaine; however, no amplification was observed at 1.6, 2.0, and 2.4 M betaine for either virus (Fig. 2D). Consequently, we determined that the optimal conditions for our subsequent RT-LAMP analyses were $65^{\circ} \mathrm{C}$ and $60^{\circ} \mathrm{C}$ for 60 min using $6 \mathrm{mM} \mathrm{MgSO}_{4}$ and no betaine for LNYV and $\mathrm{CMV}$ detection, respectively.

\section{Specificity of RT-LAMP assays for LNYV and CMV} detection. To determine the specificity of the RT-LAMP assays, we tested them using all RNA extracts from lily leaves infected with LSV, CMV from lily, LMoV, and ArMV as references, as well as lettuce leaves infected with LNYV and CMV. Following the application of RT-LAMP, only the product of the LNYV-infected lettuce sample displayed a typical ladder-like pattern using agarose gel electrophoresis. No bands were observed in healthy lettuce sample, or in the samples infected with LSV, the CMV lily isolate, $\mathrm{LMoV}$, ArMV or the CMV lettuce isolate (Fig. 3A, left). Similarly, only the product of the CMV-infected lettuce sample displayed a typical ladder-like pattern, with no bands observed in healthy lettuce sample, or in the samples infected with LSV, the CMV lily isolate, $\mathrm{LMoV}$, ArMV or LNYV (Fig. 3B, left).
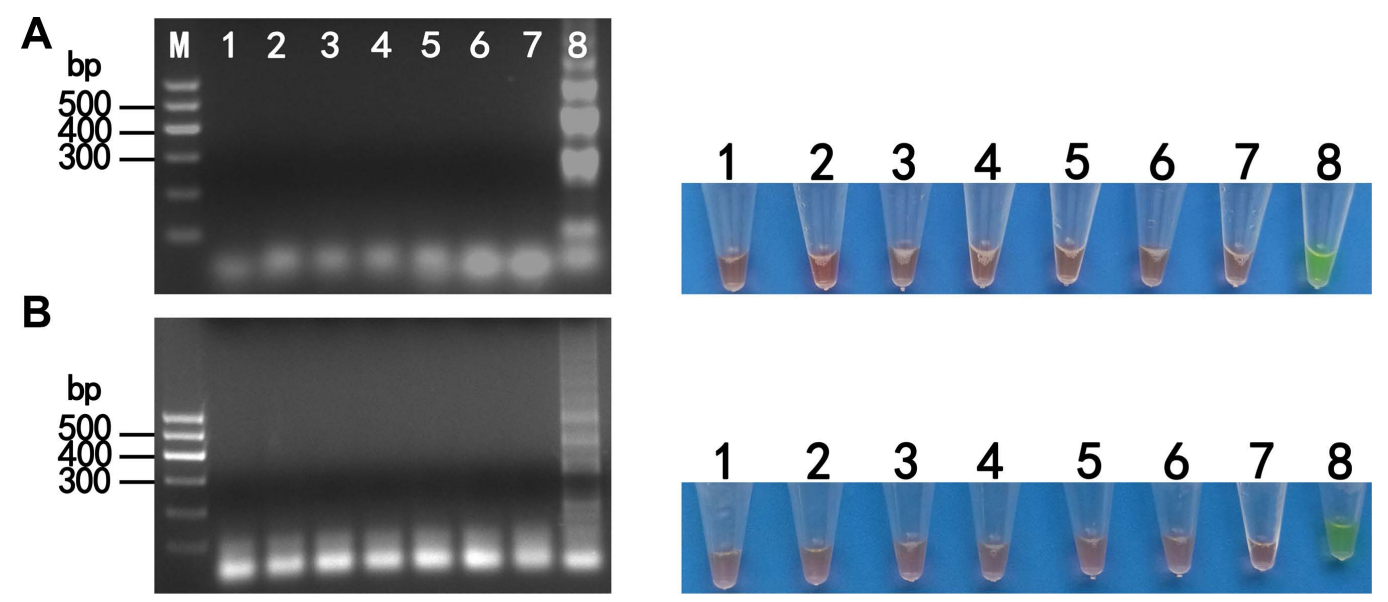

Fig. 3. Specificity of reverse transcription loop-mediated isothermal amplification (RT-LAMP) for lettuce necrotic yellows virus (LNYV) (A) and cucumber mosaic virus (CMV) (B). Amplified products from RT-LAMP were visualized by agarose gel electrophoresis (left) and by the naked eye with the addition of SYBR Green I (right). (A) Lane M: DL600 marker; lane 1: negative control; lane 2: healthy lettuce; lane 3: lily symptomless virus (LSV)-infected lily; lane 4: CMV-infected lily; lane 5: lily mottle virus (LMoV)-infected lily; lane 6: arabis mosaic virus (ArMV)-infected lily; lane 7: CMV-infected lettuce; lane 8: LNYV-infected lettuce. (B) Lane M: DL600 marker; lane 1: negative control; lane 2: healthy lettuce; lane 3: LSV-infected lily; lane 4: CMV-infected lily; lane 5: LMoV-infected lily; lane 6: ArMV-infected lily; lane 7: LNYV-infected lettuce; lane 8: CMV-infected lettuce. 
The reaction products of RT-LAMP were further confirmed using direct observation under green fluorescence by adding SYBR Green I. Only the products of LNYVand CMV-infected lettuce samples showed green fluorescence (Fig. 3A, right and 3B, right).

Sensitivity of RT-LAMP versus RT-PCR. To compare the sensitivity between RT-LAMP and RT-PCR, 10fold serial dilutions of pMD18-LNYV or pMD18-CMV plasmids were used as templates. The detection limits for LNYV were determined to be $3.5 \times 10^{-3} \mathrm{ng} / \mathrm{ml}$, namely, 3.5 $\mathrm{pg} / \mathrm{ml}$ using RT-LAMP (Fig. 4A, upper) and $3.5 \times 10^{-1} \mathrm{ng} /$ $\mathrm{mL}$ using RT-PCR (Fig. 4A, lower). The detection limits for CMV were determined to be $2.0 \times 10^{-5} \mathrm{ng} / \mathrm{ml}$, namely, $20 \mathrm{fg} / \mathrm{ml}$ using RT-LAMP (Fig. 4B, upper) and $2.0 \times 10^{-3}$ $\mathrm{ng} / \mathrm{ml}$ using RT-PCR (Fig. 4B, lower). Thus, the RTLAMP assays were more sensitive than the RT-PCR assays by a factor of 100 for both viruses. In addition, the reaction products of RT-LAMP were also directly observed using SYBR Green I fluorescence. Both methods yielded similar detection limit results for both viruses (Fig. 4A, middle and 4B, middle).

Evaluation of RT-LAMP using field-collected samples.
We analyzed 16 field samples using the RT-LAMP and RT-PCR assays. Of the 16 samples, six were positive for LNYV, which were able to be detected using both RTLAMP and RT-PCR (Fig. 5A, upper and middle). For CMV, 10 out of the 16 tested positive using RT-LAMP (Fig. $5 \mathrm{~B}$, upper) whereas only eight were positive using RTPCR (Fig. 5B, middle). We observed clearer ladder-like patterns in lanes 4, 5, 7, 8, and 9 using the RT-LAMP (Fig. $5 \mathrm{~B}$, upper), whereas the products of RT-PCR in lanes 4, 5, 7, 8, and 9 were weak (Fig. 5B, middle). Five samples were negative for both LNYV and CMV.

Products from both methods analyzed using SYBR Green I fluorescence and agarose gel electrophoresis yielded similar results for LNYV and CMV detection to those above (Fig. 5A, lower and 5B, lower).

\section{Discussion}

Although different molecular methods have been developed for LNYV and CMV detection, many require technical expertise and specialized equipment (Callaghan and Dietzgen, 2005; Deyong et al., 2005). In this study, we successfully developed a simple, sensitive and reliable method to detect both LNYV and CMV using RT-LAMP
A

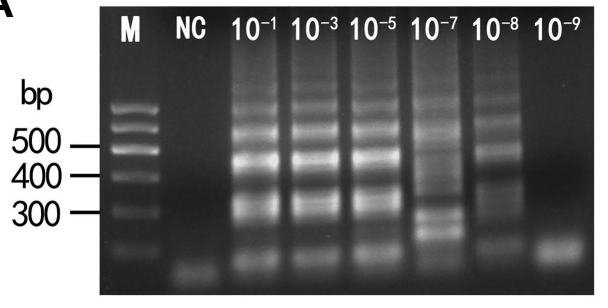

NC $10^{-1} 10^{-3} 10^{-5} 10^{-7} 10^{-8} 10^{-9}$
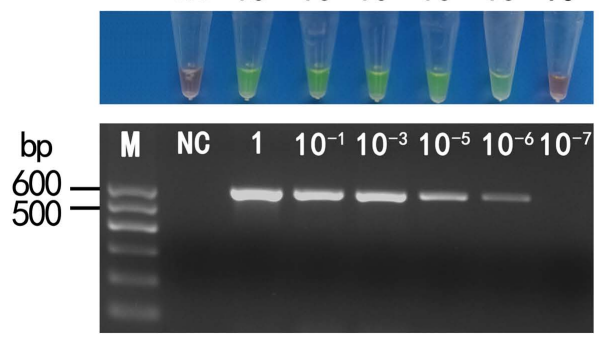

B
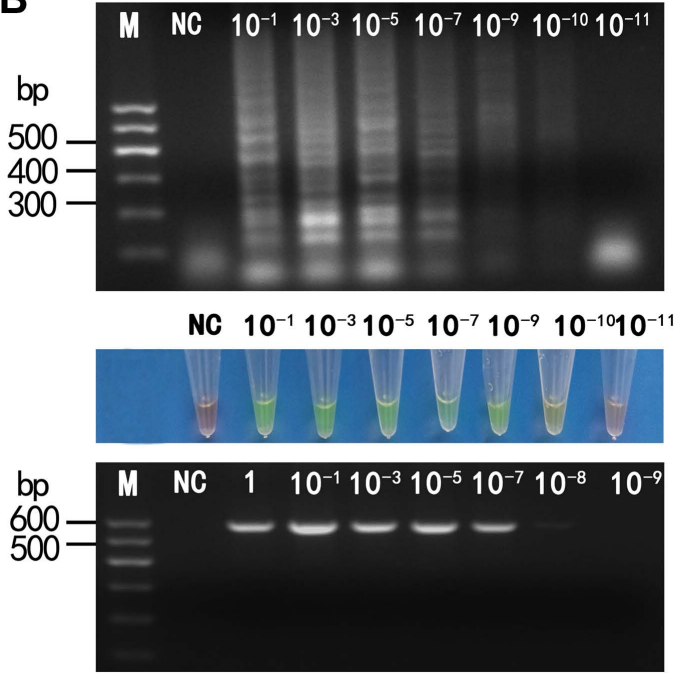

Fig. 4. Comparison of the sensitivity of detection of lettuce necrotic yellows virus (LNYV) (A) and cucumber mosaic virus (CMV) (B) by reverse transcription loop-mediated isothermal amplification (RT-LAMP) and reverse transcription polymerase chain reaction (RTPCR). The LNYV or CMV plasmid was diluted 10 -fold from the initial concentration $\left(3.5 \times 10^{5} \mathrm{ng} / \mathrm{ml}\right.$ or $\left.2.0 \times 10^{5} \mathrm{ng} / \mathrm{ml}\right) \mathrm{respectively}$ and used as a template to assess RT-LAMP and RT-PCR sensitivity for each virus. (A) LNYV. Amplified products from RT-LAMP were visualized by agarose gel electrophoresis (upper) and by the naked eye with the addition of SYBR Green I (middle). Lane M: DL600 marker; NC: negative control; lanes 3-8: LNYV plasmid dilutions; amplified products from RT-PCR were visualized by agarose gel electrophoresis (lower). (B) CMV. Amplified products from RT-LAMP were visualized by agarose gel electrophoresis (upper) and by the naked eye with the addition of SYBR Green I (middle). Lane M: DL600 marker; NC: negative control; lanes 3-9: CMV plasmid dilutions; amplified products from RT-PCR were visualized by agarose gel electrophoresis (lower). 

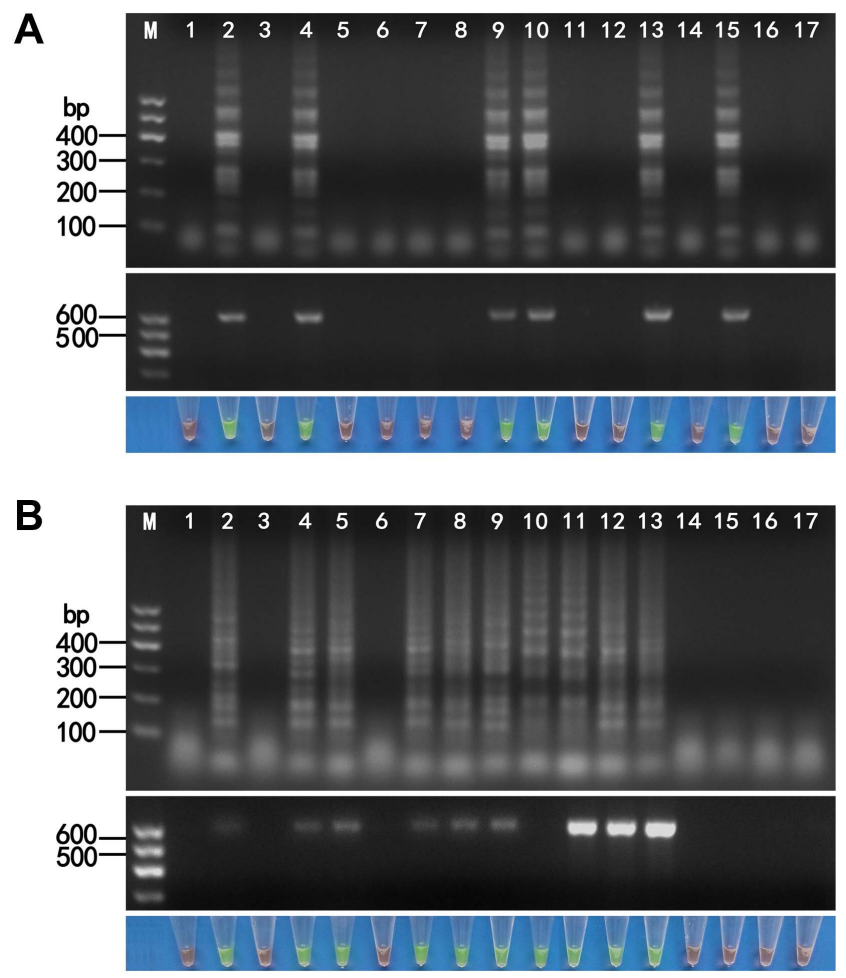

Fig. 5. By using reverse transcription loop-mediated isothermal amplification (RT-LAMP) and reverse transcription polymerase chain reaction (RT-PCR), lettuce necrotic yellows virus (LNYV) (A) and cucumber mosaic virus (CMV) (B) were detected in field-collected samples from the Lanzhou City district. Amplification products using RT-LAMP (upper), RT-PCR (middle) were visualized by agarose gel electrophoresis and by the naked eye with the addition of SYBR Green I (lower). Lane M: DL600 marker; lane 1: negative control; lanes 2-17: lettuce leaf samples.

assays that can be performed at temperatures between 58 $70^{\circ} \mathrm{C}$ and $60-70^{\circ} \mathrm{C}$ at approximately $60 \mathrm{~min}$ for LNYV and CMV respectively. We found that the RT-LAMP and RTPCR methods yielded similar results using field-collected samples for LNYV detection (Fig. 5A). When RT-LAMP and RT-PCR analyses were used to detect CMV in fieldcollected samples, the reaction products were invisible in lanes 2 and 10 using RT-PCR (Fig. 5B, middle) and were therefore considered CMV-negative. However, their amplicons did show clear ladder-like patterns using the RT-LAMP method (Fig. 5B, upper). In addition, the RTPCR products of five samples in lanes 4, 5, 7, 8, and 9 also showed weak bands (Fig. 5B, middle), but again their amplicons showed clear ladder-like patterns using RT-LAMP (Fig. 5B, upper). Because the field lettuce samples were collected at different growth stages including early seedling, rosette or lotus and heading there may well have been differences in virus concentration. We therefore speculate that the virus titer of CMV in samples 2, 4, 5, 7-10 might be relatively low and not so easily detected using RT-PCR. Further survey work needs to be undertaken to verify this conclusion. We believe these preliminary results demonstrate that our RT-LAMP assay is a reliable method with greater sensitivity than RT-PCR. The negative result in our assays of specimens 3, 6, 14, 16, 17 might be explained either by the presence of other viruses not tested in these experiments (e.g., luteovirus) or a nutrient imbalance caused by low nitrogen or iron concentrations.

We believe the key step for the success of the LAMP method is the design of the primers (Hardinge et al., 2018; Zhao et al., 2018). In this study, we designed two external and two internal primer pairs for LNYV and CMV detection. In addition, a pair of loop primers for LNYV and a single loop primer for CMV detection, were designed, which are capable of recognizing eight sequences of the $\mathrm{N}$ gene of LNYV and seven sequences of the CP gene of CMV. Our results indicated that the combination of these primers contributed to the high detection sensitivity. We found the sensitivities of both RT-LAMP assays were greater by a factor of 100 compared to the conventional RT-PCR assays (Fig. 4). With respect to the sensitivity of LAMP-based assays, our results for LNYV and CMV were consistent with those obtained by other researchers (Bhat et al., 2013; Liu et al., 2010; Zhao et al., 2018).

Standardization of the LAMP reaction mixture (especially the concentration of $\mathrm{MgSO}_{4}$ and betaine) as well as the optimum temperature and duration are also important for successful pathogen detection (Bhat et al., 2013). Our experiments served to standardize all parameters used for LNYV and CMV detection. Of particular interest was finding that the betaine-free treatment was far superior to that of the widely used addition of $0.8 \mathrm{M}$ betaine (Fig. 2D). This is consistent with results from Ma et al. (2017). An explanation for this might be that betaine inhibited the reaction efficiency of isothermal amplification reactions as found by Ma et al. (2017).

The optimum temperature for the LAMP reaction was initially achieved using a thermal cycler to maintain a constant reaction temperature. Subsequently, two further options were evaluated to ascertain their suitability for this purpose: a water bath and a heat block. We found that all three methods used to incubate RT-LAMP reactions yielded similar amplification results (data not shown), which confirmed that any device that can accurately maintain a set temperature is adequate for RT-LAMP amplification.

The products of RT-LAMP were routinely confirmed using agarose gel electrophoresis. Similarly, to other studies (Bhat et al., 2013; He et al., 2016), our experiments were 
also able to confirm that RT-LAMP products could be detected through a simple visual examination under green fluorescence using SYBR Green I. Both visual methods (gel electrophoresis and green fluorescence) yielded similar results in specificity and detection limits as well as with fieldcollected samples (Figs. 3-5). From our results, we believe green fluorescence does appear to be a suitable examination method for conducting RT-LAMP experiments in laboratories with limited facilities. However, further studies are required to develop a more practical and rapid fieldbased LAMP procedure, such as IC-RT-LAMP for lettuce crops.

The ability to detect a broad range of isolates is usually desirable for a general diagnostic assay; however, our RTLAMP assay for CMV did not react with the CMV lily isolate (Fig. 3). In a reciprocal assay conducted using a LAMP assay developed specifically for the CMV lily isolate (Zhang, unpublished data) we found no reactivity with the lettuce samples infected with CMV (data not shown). This difference may be related to viral evolution; namely, the CMV lily isolate may have evolved into a new host subgroup within the CMV subgroup I, becoming more closely adapted to lily plants while losing their capacity to infect other hosts (Liu et al., 2004; Masuta et al., 2002). Subsequent research confirmed that the host range of the CMV lily isolate was indeed narrow. While the CMV lily isolate could infect cucumbers, Datura stramonium and Phaseolus vulgaris, it could not infect normal indicator hosts of CMV include Nicotiana tabacum, Nicotiana glutinosa, and Chenopodium amaranticolor (Liang et al., 2008). A comparison between sequence data further confirmed that the sequence identity of $\mathrm{CP}$ sequences at a nucleotide level were only $77.7 \%$ between the CMV lettuce isolate (GenBank No. AJ810253) and the CMV lily isolate (GenBank No. DQ 767971). Further investigation is needed to explore how limited the host range is for the CMV lily isolate, particularly its capacity to infect lettuce and other plant species.

This study further confirmed CMV infection in lettuce crops in Lanzhou City and is the first to confirm the presence of LNYV in lettuce in China. Even with our limited collection of field samples, we were able to detect a proportion of viral infections among the 16 samples, with 6 $(37.5 \%)$ and $10(62.5 \%)$ testing positive for LNYV and CMV, respectively, using our RT-LAMP assays. In addition, we found LNYV + CMV mixed infections in 3 (18.8\%) of plants tested (Fig. 5). Similarly we also found LNYV + CMV + LMV mixed infections in 2 (12.5\%) of plants tested (Zhang, unpublished data). From our primary field survey of lettuce conducted in 2018, and from discus- sions with growers, we determined that CMV and LMV infections appear to have contributed to a reduction in yield in Lanzhou City lettuce crops. LNYV also appeared to contribute to yield losses in these crops. There is concern that once established within the main areas of production LNYV, alone or in combination CMV and LMV may cause serious economic losses to the lettuce industry in China. Consequently, it is important for lettuce growers in Gansu Province and other lettuce growing regions to consider adopting improved practical measures for virus control. The low cost, convenient and simple RT-LAMP method, being high in sensitivity and specificity, which we successfully developed for the detection of LNYV and CMV and reported here may offer growers an effective tool to maintain the production of healthy seedlings, identify sources of virus infection in alternative hosts and facilitate the timely application of insecticides for vector control.

\section{Acknowledgments}

This study was supported by the Key Technology Talent Program of the Chinese Academy of Sciences (CAS) (Grant No. 2016-65), the Lanzhou Talent Innovation and Entrepreneurship Project (Grant No. 2019-HLJC-9), the Lanzhou Chengguan District Science and Technology Project (Grant No. 2019-6-2), the Science and Technology Service Network Initiative of CAS (KFJ-STS-QYZD-120), and the Northwest Institute of Eco-Environment and Resources, CAS (Y855Z11001). We would like to thank The New Zealand Institute for Plant and Food Research, Lincoln, New Zealand, for hosting Dr Yubao Zhang as a research scholar working with John D Fletcher during 2017-2018. The authors have no conflict of interest to declare.

\section{References}

Bhat, A. I., Siljo, A. and Deeshma, K. P. 2013. Rapid detection of Piper yellow mottle virus and Cucumber mosaic virus infecting black pepper (Piper nigrum) by loop-mediated isothermal amplification (LAMP). J. Virol. Methods 193:190-196.

Blancard, D., Lot, H. and Maisonneuve, B. 2006. A color atlas of diseases of lettuce and related salad crops: observation, biology and control. Academic Press, Boston, MA, USA. 375 pp.

Bruckart, W. L. and Lorbeer, J. W. 1975. Recent occurrences of cucumber mosaic, lettuce mosaic and broad bean wilt viruses in lettuce and celery fields in New York. Plant Dis. Rep. 59:203-206.

Callaghan, B. and Dietzgen, R. G. 2005. Nucleocapsid gene variability reveals two subgroups of Lettuce necrotic yellows virus. Arch. Virol. 150:1661-1667.

Deyong, Z., Willingmann, P., Heinze, C., Adam, G., Pfunder, M., 
Frey, B. and Frey, J. E. 2005. Differentiation of cucumber mosaic virus isolates by hybridization to oligonucleotides in a microarray format. J. Virol. Methods 123:101-108.

Dietzgen, R. G. and Francki, R. I. B. 1988. Analysis of lettuce necrotic yellows virus structural proteins with monoclonal antibodies and concanavalin A. Virology 166:486-494.

El-Borollosy, A. M. and Waziri, H. M. A. 2013. Molecular characterization of a cucumber mosaic cucumovirus isolated from lettuce in Egypt. Ann. Agric. Sci. 58:105-109.

Fletcher, J. D., France, C. M. and Butler, R. C. 2005. Virus surveys of lettuce crops and management of lettuce big-vein disease in New Zealand. N. Z. Plant Prot. 58:239-244.

Fletcher, J. D., Walker, M., Davidson, M., Paull, S. and Palmer, A. 2017. Outdoor lettuce virus disease project 2016-2018 Year 1 report. Plant \& Food Research SPTS No. 14591. URL https:// www.freshvegetables.co.nz/assets/Lettuce-virus-disease-project-Report-John-Flectcher-PFR-2016-2018-Year-1-FINAL. pdf [10 May 2019].

Fry, P. R., Close. R. C., Procter, C. H. and Sunde, R. 1973. Lettuce necrotic yellows virus in New Zealand. N. Z. J. Agric. Res. 16:143-146.

Gambley, C. F., Geering, A. D. W. and Thomas, J. E. 2009. Development of an immunomagnetic capture-reverse transcriptase-PCR assay for three pineapple ampeloviruses. J. Virol. Methods 155:187-192.

Hardinge, P., Kiddle, G., Tisi, L. and Murray, J. A. H. 2018. Optimised LAMP allows single copy detection of 35Sp and NOSt in transgenic maize using bioluminescent assay in real time (BART). Sci. Rep. 8:17590.

He, X., Xue, F., Xu, S. and Wang, W. 2016. Rapid and sensitive detection of Lily symptomless virus by reverse transcription loop-mediated isothermal amplification. J. Virol. Methods 238:38-41.

Higgins, C. M., Chang, W.-L., Khan, S., Tang, J., Elliott, C. and Dietzgen, R. G. 2016. Diversity and evolutionary history of lettuce necrotic yellows virus in Australia and New Zealand. Arch. Virol.161:269-277.

Jackson, A. O., Dietzgen, R. G., Goodin, M. M., Bragg, J. N. and Deng, M. 2005. Biology of plant rhabdoviruses. Annu. Rev. Phytopathol. 43:623-660.

Koenig, R. 1981. Indirect ELISA methods for broad specificity detection of plant viruses. J. Gen. Virol. 55:53-62.

Krause-Sakate, R., Mello, R. N., Pavan, M. A., Zambolim, E. M., Carvalho, M. G., Le Gall, O. and Zerbini, F. M. 2001. Molecular characterization of two Brazilian isolates of Lettuce mosaic virus with distinct biological properties. Fitopatol. Bras. 26:153-157.

Liang, Q.-L., Wei, L.-X. and Xu, B.-L. 2008. Study on the host range of viruses infecting ornamental lily. J. Gansu Agric. Univ. 43:94-96 (in Chinese).

Liu, W.-H., Hong, J., Chen, J.-S. and Ye, M.-Q. 2004. Cloning and phylogenetic analysis of $C P$ gene for two CMV isolates infecting Lilium cv. Oriental Hybrids. J. Agric. Biotechnol. 12:442-445 (in Chinese).
Liu, Y., Wang, Z., Qian, Y., Mu, J., Shen, L., Wang, F. and Yang, J. 2010. Rapid detection of tobacco mosaic virus using the reverse transcription loop-mediated isothermal amplification method. Arch. Virol. 155:1681-1685.

Ma, C., Wang, Y., Zhang, P. and Shi, C. 2017. Accelerated isothermal nucleic acid amplification in betaine-free reaction. Anal. Biochem. 530:1-4.

Masuta, C., Seshimo, Y., Mukohara, M., Jung, H. J., Ueda, S., Ryu, K. H. and Choi, J. K. 2002. Evolutionary characterization of two lily isolates of Cucumber mosaic virus isolated in Japan and Korea. J. Gen. Plant Pathol. 68:163-168.

Notomi, T., Okayama, H., Masubuchi, H., Yonekawa, T., Watanabe, K., Amino, N. and Hase, T. 2000. Loop-mediated isothermal amplification of DNA. Nucleic Acids Res. 28:e63.

Palukaitis, P., Roossinck, M. J., Dietzgen, R. G. and Francki, R. I. B. 1992. Cucumber mosaic virus. Adv. Virus Res. 41:281348.

Parida, M., Sannarangaiah, S., Dash, P. K., Rao, P. V. L. and Morita, K. 2008. Loop mediated isothermal amplification (LAMP): a new generation of innovative gene amplification technique; perspectives in clinical diagnosis of infectious diseases. Rev. Med. Virol. 18:407-421.

Ragozzino, A., Alioto, D., Iengo, C. and Iego, C. 1989. The yellowing virus and mycoplasma diseases of lettuce in Campania and Latium regions. Riv. Patol. Veget. 25:15-19.

Ravindran, A., Levy, J., Pierson, E. and Gross, D. C. 2012. Development of a loop-mediated isothermal amplification procedure as a sensitive and rapid method for detection of ' $\mathrm{Can}$ didatus Liberibacter solanacearum' in potatoes and psyllids. Phytopathology 102:899-907.

Roossinck, M. J. 1999. Cucumoviruses (Bromoviridae) general features. In: Encyclopedia of virology, 2nd ed., eds. by L. Granoof and R. G. Webster, pp. 315-320. Academic Press, San Diego, CA, USA.

Rubio-Huertos, M. and Garcia-Hidalgo, F. 1982. A rhabdovirus resembling lettuce necrotic yellows from lettuce in Spain. Phytopathol. Z. 103:232-238.

Stubbs, L. L. and Grogan, R. G. 1963. Necrotic yellows: a newly recognized virus disease of lettuce. Aust. J. Agric. Res. 14:439-459.

Tordo, N., Benmansour, A., Calisher, C., Dietzgen, R. G., Fang, R.-X., Jackson, A. O., Kurath, G., Nadin-Davis, S., Tesh, R. B. and Walker, P. J. 2005. Family Rhabdoviridae. In: Virus taxonomy: eighth report of the International Committee on the Taxonomy of Viruses, 2nd ed., eds. by C. M. Fauqent, M. A. Mayo, J. Maniloff, U. Desselberger and L. A. Ball, pp. 623644. Elsevier Academic Press, San Diego, CA, USA.

Viswanathan, R., Ganesh Kumar, V., Karuppaiah, R., Scindiya, M. and Chinnaraja, C. 2013. Development of duplex-immunocapture (Duplex-IC) RT-PCR for the detection of sugarcane streak mosaic virus and sugarcane mosaic virus in sugarcane. Sugar Tech. 15:399-405.

Wikipedia: the free encyclopedia. 2019. Lettuce. URL https://en.wikipedia.org/w/index.php?title=Lettuce\&old 
$\mathrm{id}=894244593$ [10 May 2019].

Zhang, Y., Wang, Y., Xie, Z., Yang, G., Guo, Z. and Wang, L. 2017. Simultaneous detection of three lily viruses using Triplex IC-RT-PCR. J. Virol. Methods 249:69-75.

Zhao, K., Liu, Y. and Wang, X. 2010. Reverse transcription loopmediated isothermal amplification of DNA for detection of Barley yellow dwarf viruses in China. J. Virol. Methods
169:211-214.

Zhao, B., Yang, D., Zhang, Y., Xu, Y., Zhao, X., Liang, J., Fan, X., Du, Y., Zhu, Z., Shi, B., Zhang, Q., Zhang, X., Cai, Y. and Zhao, K. 2018. Rapid visual detection of lily mottle virus using a loop-mediated isothermal amplification method. Arch. Virol.163:545-548. 